\title{
A nexus approach to the responsibility of the European Border and Coast Guard: From individual to systemic accountability
}

\author{
Mariana Gkliati \\ Institute of Immigration Law, Leiden University
}

Seminar, Controlling Migration through Cooperation: Recent trends in the externalisation of migration control

Friday 2 February 2018

Tilburg University

\section{Introduction}

With 146 joint surveillance operations at the EU external borders since 2005, and with a budget of 232 million EUR, Frontex and its evolution, the European Border Guards Agency (EBCGA) has become one of the most important actors in border enforcement in Europe.

The European Border and Coast Guard (EBCG) is one of the most prominent examples of cooperation in the area of migration control, as well as one of the first, as it has been on the radar of the European Commission since 2002. Frontex joint operations have laid the groundwork for the externalisation of migration control, as well as cooperation among member states, third states, and other agencies. The agency has become the symbolism of this cross-border cooperation, essentially embodying in popular imaginary and the public debate both the cross-border cooperation and the securitisation characterising EU migration policies.

As they incorporate the securitisation approach, Frontex operations have inherent human rights sensitivities. When these materialise into real violations, the multiplicity of actors involved raises questions as to who bears responsibility for such violations, and how these responsibilities should be addressed by judicial bodies.

Such interaction of multiple actors leads to a nexus of responsibilities, both individual and collective, positive and negative, direct or indirect, that is hard to disentangle. The connections between the responsibility of member states and that of the agency often lead to a non-singular answer to the question of the one responsible, which is not accommodated by the existing paradigm of legal accountability. Thus, this paper suggests a different approach to accountability, named 'systemic accountability', arguing from the perspective of justice, the rule of law, and strategic litigation. 
Finally, given that responsibility is only relevant when it is followed by its practical manifestation in courts, the present contribution looks briefly into the new pathways of legal accountability at the European level opened by the Lisbon Treaty, and how they could accommodate the new approach of systemic accountability.

Adding a note on terminology, 'responsibility' is used here in the meaning it has in international law, as it has been authoritatively formulated in the classic Chorzow Factory judgment: 'It is a principle of international law that the breach of an engagement involves an obligation to make reparation in an adequate form.'

Inspired by the analytical framework developed by Bovens, Curtin and Hart, ${ }^{2}$ I use the term 'accountability' in the sense of 'answering for decisions on how governance is being exercised'. Several forms of accountability can be identified, such as administrative, democratic, and social accountability. This paper deals with 'legal accountability', i.e. the actor's subjection to substantive legal control and formal judicial mechanisms of accountability. $^{3}$

In other words, while 'responsibility' refers to the obligation for reparations in case of breach of an engagement, 'legal accountability' would be the possibility to be held responsible, to answer for breaches of international obligations before courts.

\section{European Border and Coast Guard}

\subsection{Frontex and its role in integrated border management}

Frontex is an essential element of cross-border cooperation, a vital aspect of European integration, which has been defined as 'a more or less institutionalised collaboration between contiguous subnational authorities across national borders'. ${ }^{4}$ This cross-border cooperation

\footnotetext{
${ }^{1}$ Permanent Court of International Justice, Case Concerning the Factory at Chorzów (Claim for Indemnity), jurisdiction, [1927] Publ. PCIJ, Series A, judgment no. 8, p. 21.

2 Mark Bovens, Deirdre Curtin, Paul 't Hart (eds.), The Real World of EU Accountability. What Deficit?, 2010, Oxford University Press.

3 Bovens, the Real World of EU Accountability, p. 5 (?)

${ }^{4}$ Perkmann M, 2003, Cross-border regions in Europe - Significance and drivers of regional cross-border cooperation, EUROPEAN URBAN AND REGIONAL STUDIES, Vol: 10, Pages: 153-171.
} 
has materialised at the EU level in the conceptual framework of European Integrated Border Management, which has been defining EU policies since the beginning of the 2000's. ${ }^{5}$

It aims to control access to EU territory on the basis of a four-tier system, which comprises of cooperation with third countries, in particular countries of origin (e.g. visa policies), cooperation with neighbouring third countries, control of the external borders, and control measures within the Schengen area. ${ }^{6}$

The establishment of a European border control agency has been deemed since early on crucial for the effective implementation of integrated border management. Frontex was created in 2004 with the initiative of Italy, Belgium, France, Germany, and Spain ${ }^{7}$ and reflected the security concerns of the member states, after the abolition of the internal borders, especially in the face of the Union's enlargement towards Eastern Europe, along with their commitment to closer integration. ${ }^{8}$ The agency was seen as a manifestation of solidarity and a useful tool for responsibility sharing, which would allow for the more efficient use of resources and expertise, and would at the same time further European integration. ${ }^{9}$

Initially, the project concerned a 'European Border Police' or a 'European Border Guard' that would be in the centre of an integrated approach combining infrastructures, information exchange, cooperation and coordination, border management, and police cooperation. ${ }^{10}$ It would support but not replace national border police forces. ${ }^{11}$ The idea of the body being vested with full operational powers effectively replacing the national border authorities, as it

\footnotetext{
${ }^{5}$ See Sergio Carrera, CEPS Working Document No. 261/March 2007, The EU Border Management Strategy FRONTEX and the Challenges of Irregular Immigration in the Canary Islands, available at http://aei.pitt.edu/7385/1/1482.pdf (last accessed 15/01/2018).

${ }^{6}$ Council of the European Union, Justice and Home Affairs, 2768th Council Meeting, Brussels, 4-5 December 2006, Press Release, 15801/06.

${ }^{7}$ Council of the European Union: Feasibility study for the setting up of the "European Border Police" - final report, Rome, 2002, p. 5.

${ }^{8}$ Council of the European Union: Feasibility study for the setting up of the "European Border Police" - final report, p. 5.

${ }^{9}$ House of Lords, European Union - Ninth Report, CHAPTER 3: integrated border management and a European border guard, European Union Committee Publications, par. 22, available at:

http://www.publications.parliament.uk/pa/ld200203/ldselect/ldeucom/133/13305.htm (last accessed: 08.11.2016); For a critical analysis on the establishment of Frontex see Perkowski, N. (2012). A normative assessment of the aims and practices of the European border management agency Frontex. Refugee Studies Centre, Working Paper Series No. 81.

10 'it should be highlighted that border management is not focusing solely on the immigration aspect but also on other purposes customs purposes, traffic security, prevention of the entry of dangerous or illegal goods, identification of persons wanted for arrest or extradition (...)". Communication from the Commission on a Common Policy on Illegal Immigration. Presidency Conclusions at the European Council meeting in Laeken: for a more Effective Control of the External Borders. The JHA Council (February 28, 2002), point 4.4.

${ }^{11}$ European Council, Plan for the management of the external borders of the Member states of the European Union, Council document 10019/02, 14 June 2002, paras 118-120.
} 
was the intention of the Commission and the European Parliament, ${ }^{12}$ was discussed and dismissed for the time being due to the sovereignty concerns of the member states. ${ }^{13}$

The name has proven controversial with member states, including the UK, Finland and Sweden, that expressed reservations about a fully integrated system of border management represented in a European Border Police Corps. ${ }^{14}$ The name was dropped by the European Council already in $2001,{ }^{15}$ but the European Commission insisted on it as a longer-term plan that would result from progressive integration. ${ }^{16}$

The first crucial step towards this long-term progressive integration process was the establishment of Frontex in Warsaw in 2004 with Council Regulation (EC) 2007/2004 (Frontex Regulation). ${ }^{17}$

Its legal basis today is found in Articles 77 and 79 TFEU, which reflect the dynamics of the Schengen system with free movement complemented with efficient control of irregular migration especially at the external borders and a growing emphasis on integrated border management. The agency aims to ensure effective border management by coordinating and assisting the member states in the surveillance and control of the external borders.

\footnotetext{
${ }^{12}$ Jorry, H. (2007) Construction of a European Institutional model for managing operational cooperation at the EU's external borders: Is the FRONTEX agency a decisive step forward?, CEPS Research Paper, No. 7, p. 2. ${ }^{13}$ Jörg Monar, The Project of a European Border Guard: Origins, Models and Prospects in the Context of the EU's Integrated External Border Management, in Marina Caparini and Otwin Marenin (eds), Borders and Security Governance, Managing Borders in a Globalised World, LIT Verlag Münster, 2006, Chapter 10, pp. 4, 5; Wolff, S. (2008) Border management in the Mediterranean: Internal, external and ethical challenges, Cambridge Review of International Affairs, 21(2), pp. 253-271.

${ }^{14}$ House of Lords, European Union - Ninth Report, CHAPTER 3: integrated border management and a European border guard, European Union Committee Publications, par. 30, available at: http://www.publications.parliament.uk/pa/ld200203/ldselect/ldeucom/133/13305.htm (last accessed: 08.11.2016); Jörg Monar, The Project of a European Border Guard: Origins, Models and Prospects in the Context of the EU's Integrated External Border Management, in Marina Caparini and Otwin Marenin (eds), Borders and Security Governance, Managing Borders in a Globalised World, LIT Verlag Münster, 2006, Chapter 10, p. 2.

${ }^{15}$ Laeken European Council of 14-15 December 2001.

${ }^{16}$ Commission Communication to the Council and the European Parliament entitled "Towards integrated management of the external borders of the Member states of the European Union", 2002; Jörg Monar, The Project of a European Border Guard: Origins, Models and Prospects in the Context of the EU's Integrated External Border Management, in Marina Caparini and Otwin Marenin (eds), Borders and Security Governance, Managing Borders in a Globalised World, LIT Verlag Münster, 2006, Chapter 10, p. 2.

${ }^{17}$ Council Regulation (EC) 2007/2004/. This Regulation was later amended by Regulation (EC) No 863/2007 of the European Parliament and of the Council of 11 July 2007 establishing a mechanism for the creation of Rapid Border Intervention Teams (Rabit Regulation) and Council Regulation (EC) No 1168/2011 of the European Parliament and the Council of 25 October 2011 amending Council Regulation (EC) No 2007/2004 establishing a European Agency for the Management of Operational Cooperation at the External Borders of the Member states of the European Union.
} 


\subsection{The development of the EBCG}

Since it became operational, in May 2005, the agency has witnessed considerable growth in its operational capacity. Its staff has increased from 43 members in $2005^{18}$ to 330 in $2016^{19}$. Furthermore, from an initial budget of $€ 6$ million $^{20}$, which was enough only to cover the staffing and administration costs, ${ }^{21}$ the agency handled funds of $€ 232$ million in $2016^{22}$, more than half of which is allocated to joint operations. It currently manages a pool of almost 3,000 border experts seconded by member states, ${ }^{23}$ and a rich pool of technical equipment. ${ }^{24}$

Its mandate has developed in parallel to the growth of its financial and human resources with two amendments of its founding regulation in 2007 (hereafter RABIT Regulation) ${ }^{25}$ and in $2011,{ }^{26}$ which expanded the agency's operational powers, while its mandate is also developing

18 Council of the European Union, "Strengthening the European external borders agency Frontex - Political Agreement between Council and Parliament", 11916/11, Presse 192, Brussels, 23 June 2011(a).

${ }^{19}$ Frontex Executive Director, Fabrice Leggeri, hearing before UK Parliament, House of Lords, available at http://parliamentlive.tv/Event/Index/1e48fc9c-722d-4cc1-9c85-1e5f772630d9.

$20 \quad$ Council of the European Union, "Strengthening the European external borders agency Frontex Political Agreement between Council and Parliament", 11916/11, Presse 192, Brussels, 23 June 2011(a).

21 Pollak Johannes, Slominski Peter, 'Experimentalist but not Accountable Governance? The Role of Frontex in Managing the EU's External Borders', West European Politics, Volume 32, Issue 5, 2009, p. 909.

22 Frontex, Work Programme 2016.

${ }^{23}$ Frontex, Annual Information on the Commitments of Member states to the European Border Guard Teams and the Technical Equipment Pool, Report 2015, p. 7, available at http://frontex.europa.eu/assets/About_Frontex/Governance_documents/EBGT_TEP_Report/20150401_Frontex_ Annual_Report_to_the_EP_on_the_commitments_of_the_MS_to_the_EBGT_and_the_TEP.pdf

${ }^{24}$ Frontex, Annual Information on the Commitments of Member states to the European Border Guard Teams and the Technical Equipment Pool, Report 2015, p. 9, available at

http://frontex.europa.eu/assets/About_Frontex/Governance documents/EBGT_TEP_Report/20150401_Frontex Annual Report to the EP on the commitments of the MS to the EBGT and the TEP.pdf

25 Council Regulation (EC) No 2007/2004 of 26 Oct. 2004 establishing the European Agency for the Management of Operational Cooperation at the External Borders of the Member states of the European Union, [2004] OJ L 349/1 (Frontex Regulation), as amended by Regulation (EC) No 863/2007 of the European Parliament and of the Council of 11 July 2007, establishing a mechanism for the creation of Rapid Border Intervention Teams and amending Council Regulation (EC) No 2007/2004 as regards that mechanism and regulating the tasks and powers of guest officers, [2007] OJ L 199/30 (RABIT Regulation).

26 Regulation (EU) No 1168/2011 of the European Parliament and of the Council of 25 October 2011 amending Council Regulation (EC) No 2007/2004 establishing a European Agency for the Management of Operational 
on an ad hoc basis. ${ }^{27}$ The European Border and Coast Guard Regulation, ${ }^{28}$ which replaced the Frontex Regulation in 2016, made a marked change in the status and operational role of Frontex. ${ }^{29}$

This gradual approach to the development of mandate and capabilities, where the agency is vested with new powers almost every two years, was a necessary reconciliation between on the one hand the Commission's vision of a totally-integrated system border management led by a fully-fledged corps of border guards, and on the other hand the sovereignty concerns of member states.

With the EBCG, Schengen comes closer to a fully integrated scheme of border management, but still the plan falls short of the Commission's original idea of a permanent European Border Police Corps, as the agency still relies on the cooperation of member states to provide information, staff and equipment, but also for the conduct of a joint operation as a whole. ${ }^{30}$

\subsection{Actors involved}

Cooperation at the External Borders of the Member states of the European Union.; Steve Peers has produced a codified version, Statewatch analysis, The Frontex Regulation Consolidated text after 2011 amendments, available here: http://www.statewatch.org/analyses/no-140-frontex-reg-text.pdf.

${ }^{27}$ Frontex had already been participating in operations in the context of bilateral agreements with third countries, e.g. Hera Operation, 2006, before that was foreseen in its founding Regulation in 2011; Operations Triton and Poseidon are awarded a significant 'search and rescue' character after several incidents of mass drowning in the Mediterranean. Commission statement about Triton, October 2014, available at:

http://europa.eu/rapid/press-release MEMO-14-566 en.htm (last accessed 08.05.2015); Statement of the special meeting of the European Council, 23 April 2015, available at $h$ ttp://www.consilium.europa.eu/en/press/pressreleases/2015/04/23-special-euco-statement/ (last accessed 08.05.2015).

${ }^{28}$ Regulation 2016/1624 of the European Parliament and of the Council of 14 September 2016 on the European Border and Coast Guard and amending Regulation (EU) 2016/399 of the European Parliament and of the Council and repealing Regulation (EC) No 2007/2004, Regulation (EC) No 863/2007 and Council Decision 2005/267/EC.

${ }^{29}$ Steve Peers, The Reform of Frontex: Saving Schengen at Refugees' Expense?, EU Law Analysis blog, 16 December 2015, available here: http://eulawanalysis.blogspot.n1/2015/12/the-reform-of-frontex-savingschengen.html (last visited 01.03.2016.

${ }^{30}$ It has been argued that further supranationalisation to the extent that a European system of border guards would fully replace national coast guards, would be in violation of the division of competence between the EU and its Member states (Art. 72 TFEU). Roberta Mungianu, Frontex and Non-Refoulement: The International Responsibility of the EU, Cambridge University Press 2016, p. 43. 
In fact, the EBCG consists of the European Border and Coast Guard Agency (EBCGA) and of the national authorities of member states which are responsible for border management, including coast guards, and to the extent that they carry out border control tasks. ${ }^{31}$

Integrated management of the common borders becomes under the Regulation a 'shared responsibility' of member states and the agency. ${ }^{32}$ Member states retain the primary responsibility to control their part of the external borders, ${ }^{33}$ 'in close cooperation with the agency, ${ }^{34}$ while the stated role of the agency is to support them by reinforcing, assessing, and coordinating their actions. ${ }^{35}$ Other member states participate in the operation though contributing staff and technical resources and financing the operation.

Further, a significant role is reserved for third states. Building cooperation with neighbouring countries and countries of origin and transit is an integral part of the EU's Integrated Border Management (IBM). Frontex has concluded as of June 2012, working arrangements with 18 countries. ${ }^{36}$ The aim is that the third countries are assisted so that they are able to successfully stop the departure of immigrant vessels aiming to reach Europe, intercept migrant vessels or readmit third country nationals and return them to their respective countries of origin. Since 2016, EBCG has the mandate to launch joint operations in the territory of a third state, hosted and carried out by that third state. ${ }^{37}$ This new possibility will be operationalised with agreements that are to be concluded first with Serbia and Macedonia. ${ }^{38}$

\subsection{Joint operations in a nutshell}

Before proceeding to the assessment of responsibility for misconduct, it would be useful to apply a birds' eye's view to the work of the EBCG.

\footnotetext{
${ }^{31}$ Art. 3 EBCG Regulation.

${ }^{32}$ EBCG Regulation, Article 5(1), preambular par. 6.

${ }^{33}$ EBCG Regulation, Article 5(1), preambular par. 6.

${ }^{34}$ EBCG Regulation, Article 5(2), preambular par. 6.

${ }^{35}$ EBCG Regulation, Article 5(3), preambular par. 6.

${ }^{36}$ Frontex website, Frontex signs working arrangement with State Border Service of Azerbaijan http://www.frontex.europa.eu/news/frontex-signs-working-arrangement-with-state-border-service-of-azerbaijanNuexEl.

${ }^{3737}$ EBCG Regulation, Article 54(3).

${ }^{38}$ Second Report from the Commission to the European Parliament, the European Council and the Council on the operationalisation of the European Border and Coast Guard, Brussels, 2.3.2017, COM(2017) 201 final, p. 10.
} 
First of all, EBCG conducts joint operations, pilot projects, and rapid border interventions (swift assistance for 'specific and disproportionate challenges') in the form of joint return operations or of joint surveillance operations of the land, air, or sea external borders.

An operation is hosted by a member state, the national border guard of which takes the lead in implementing the operational plan. Other member states contribute with seconded border guards and other experts, such as translators, which staff the EBCG teams and the European Return Intervention teams, and with equipment which they have made available at the Technical Equipment Pool. The agency's own staff is not part of the EBCG and Return Intervention teams also referred to as 'guest officers'. These are the physical actors of the operation on the ground, and their powers and tasks are defined in Art. 40 EBCG Regulation. The effectiveness of the agency depends on the actual availability of the staff and assets registered in the pools.

Frontex organises and coordinates the operation, deploys experts and equipment from the pools mentioned above, in accordance with the needs identified in the operational plan, which is drawn up by the agency's Executive Director and agreed upon by the host member state. The operational plan is binding and covers all aspect necessary for carrying out a joint operation, including the division of tasks and responsibilities, the composition of the EBCG teams, and command and control provisions. ${ }^{39}$

A joint operation may be initiated by a request of a member state, and approved by Frontex, or upon the recommendation of the Executive Director, with the consent of the host member state. ${ }^{40}$ In exceptional circumstances, when the member state is unwilling or unable to cooperate, and there is urgent need for action at the external borders, the operation or rapid intervention may be launched upon the initiative of the agency, through the Commission and the Council.

Decisions concerning the launch of an operations, as well as others concerning the content of the operational plan are made on the basis of research and risk analysis conducted by the agency, taking into account the situational picture provided by EUROSUR, and the information of the vulnerability assessment, which evaluates the capacity and readiness of a

\footnotetext{
39 Art. 16 EBCG Regulation.

${ }^{40}$ For a summary of the main joint border control operations implemented by Frontex, see Fink M, 'Frontex and Human Rights Responsibility in "Multi-Actor Situations" under the ECHR and EU Public Liability Law' (Leiden University, EM Meijers Instituut 2017), p. 49.
} 
member state to manage their section of the external borders. ${ }^{41}$ In this regard, the agency also has an important role in the collection and processing of data, which it may exchange with member states and other agencies in the context of a common information-sharing environment. $^{42}$

Apart from the organisation of the operation, and the deployment of staff and equipment, Frontex also finances (and co-finances) the operations, and coordinates the different actors participating in them. It monitors and supervises the operations as well as the general capacity and conduct of host member states, including compatibility with fundamental rights.

The members of the EBCG teams are seconded by the member states and under the direct command of the authorities of the host state, which follow the operational plan. A Frontex Coordinating Officer, who belongs to the agency's own staff monitors the instructions given and the overall compliance with the operational plan, including the protection of fundamental rights. She may communicate the views of the agency to the national authorities, which should be followed to the extent possible, and will report back to the Executive Director. ${ }^{43}$ The seconded officers remain subject to the disciplinary powers of their home state. ${ }^{44}$

As the previous section has shown the powers of Frontex range from initiating, organizing, and coordinating joint border surveillance operations and pilot projects, as well as return operations upon request of a member state or on its own initiative, to monitoring the capacity and readiness of the member states to effectively face migratory pressures and possible crisis at their borders, and imposing measures when deemed necessary with or without the consent of the host member state. The agency also has an important role in research and risk analysis, as well as the management of EUROSUR. ${ }^{45}$

These activities are inherently sensitive to human rights violations. Tensions between EBCG operations and human rights and relevant criticisms have repeatedly been expressed by civil society ${ }^{46}$ and academia. ${ }^{47}$ Rights that seem to be particularly at stake are the right to non-

\footnotetext{
${ }^{41}$ Arts. 15, 17 EBCG Regulation.

${ }^{42}$ Arts. 9, 10 EBCG Regulation.

${ }^{43}$ Arts. 21, 22 EBCG Regulation.

${ }^{44}$ Art. 21 EBCG Regulation.

45 The tasks of the agency are listed in Art. 8 EBCG Regulation.

${ }^{46}$ AMNESTY INTERNATIONAL(2007)Report 2007: The State of the World's Human Rights, p. 50;
} AMNESTY INTERNATIONAL(2008) Report 2008: The State of the World's Human Rights, p. 276; ECRE \& REFUGEE COUNCIL(2007) Refugee Council and the European Council on Refugees and Exiles (ECRE) Joint Response to Select Committee on the European Union Sub-Committee F (Home Affairs): Frontex Inquiry, available at https://www.refugeecouncil.org.uk/assets/0001/6311/FrontexSept2007.pdf. 
refoulement and prohibition from torture, along with the right to asylum and the right to an effective remedy, the prohibition of collective expulsion, as well as the right to privacy and protection of personal data. When these sensitivities materialize into real violations, the need arises to establish the responsible actor in order to protect the rights of the individual.

\section{Responsibility in EBCG operations}

As established above, there are multiple actors involved in the context of an EBCG operation, each with their level of involvement that is nevertheless not absolutely clear or independent from the involvement of others. In such cases, the multiplicity of actors can potentially create confusion as to the bearer of responsibility and may result in gaps in the effective legal protection of those affected by immigration control. ${ }^{48}$

\subsection{Responsibilities of States and International Organizations, a legal framework}

The EU has established its own framework concerning the liability of its member states, or its own institutions, organs, and agencies. However, the EU legal framework is not sufficient to address all issues arising in the context of joint operations, in particular when multiple actors are involved. In such cases, we may seek guidance in international law.

A framework for dealing with responsibility under international law is in place since 2001, when the International Law Committee (ILC) adopted the Articles on the Responsibility of States (ARS). When the ARS were almost complete, the UN General Assembly recommended

\footnotetext{
${ }^{47}$ CARRERA, S.(2008) The EU Border Management Strategy: Frontex and the Challenges of Irregular Immigration in the Canary Islands , CEPS; BALDACCINI, A. (2010) 'Extraterritorial Border Controls in the EU: The Role of Frontex in Operations at Sea',229-257 in Ryan, B. \& Mitsilegas, V. (eds.) Extraterritorial Immigration Control: Legal Challenges. Leiden, The Netherlands, Martinus Nijhoff Publishers.

48 European Parliament Civil Liberties, Justice and Home Affairs Department, Guild Elspeth, Carrera Sergio, Den Hertog Leonhard, Parkin Joanna (Rapporteurs), 'Implementation of the EU Charter of Fundamental Rights and its Impact on EU Home Affairs Agencies Frontex, Europol and the European Asylum Support Office (EASO)', 2011, p. 103, available at http://www.europarl.europa.eu/meetdocs/2009 2014/documents/libe/dv/02 study fundamental rights /02 stud y fundamental rights en.pdf (last accessed 02.04.2015); A. Baldaccini, "Extraterritorial Border Controls in the EU: The Role of Frontex in Operations at Sea", in B. Ryan and V. Mitsilegas (eds), Extraterritorial Immigration Control: Legal Challenges, Leiden: Martinus Nijhoff Publishers, 2010, p. 230.
} 
that the ILC ${ }^{49}$ engages in the codification of the law of international responsibility of international organisations. ${ }^{50}$ ILC completed its work in 2011 producing the Draft Articles on the Responsibility of International Organizations (hereafter ARIO), ${ }^{51}$ which govern the rules under which an international organisation incurs responsibility for breaches of its international obligations. Both instruments are sources of international law and legally binding to the extent that they codify rules of customary international law. Concerning ARIO in particular, as the responsibility of international organisations has not been considered widely in state practice, the binding nature of ARIO is limited to the extent that it is accepted by states and international organisations. ${ }^{52}$ In this regard, ARIO have been considered extensively by the European Court of Human Rights (ECtHR), ${ }^{53}$ and national courts. ${ }^{54}$

Every internationally wrongful act of a state or international organisation brings upon the international responsibility of that state or organisation (Arts. 1 ARS, 3 ARIO). This act should be in breach of an international obligation and attributed to the state or international organisation (Arts. 2 ARS, 4 ARIO). Although there is a plethora of legal interpretations and issues to be raised concerning the terms 'act', 'attribution', 'breach' or even 'international obligation', this paper will focus on the relevant rules of attribution, while briefly looking into the responsibility of each of the actors.

By virtue of Arts. 4-11 ARS, governing the attribution of an act to a state, the responsibility of the host member state seems to be an obvious conclusion. That state hosts and carries out the operation conducted in its territory, and the guest officers are under its command. Any violation arising during such an operation, for instance, a push back or abuse of those apprehended can be directly attributable to that state.

\footnotetext{
${ }^{49}$ The International Law Commission is a subsidiary organ to the UN General Assembly, established in 1947 with the mandate to progressively develop and codify international law. Statute of the International Law Commission in United Nations General Assembly Resolution 176/II, 21 November 1947.

${ }^{50}$ United Nations General Assembly, Resolution 56/82 of 12 December 2001. This mandate includes 'the preparation of draft conventions on subjects which have not yet been regulated by international law or in regard to which the law has not yet sufficiently developed in the practice of State' and 'the more precice formulation and systematization of rules of international law in fields where there already has been extensive State practice, precedent and doctrine'. Statute of the International Law Commission, Art. 15.

${ }_{51}$ Draft articles on responsibility of international organisations, with commentaries. Report of the International Law Commission on the work of its sixty-third session, 26 April to 3 June and 4 July to 12 August 2011 (A/66/10and Add.1).

${ }_{52}^{52}$ Yearbook of the International Law Commission, 2011, Vol. II, Part Two, p. 3.

${ }^{53}$ e.g. Behrami and Behrami v France and Saramati v. France, Germany and Norway, App Nos. 71412/01 and 78166/01, decision of 2 May 2007; Al-Jedda v United Kingdom, App No. 27021/08, judgment of 7 July 2011.

${ }^{54}$ e.g. House of Lords, United Kingdom of Great Britain and Northern Ireland, R (on the application of AlJedda) $\mathrm{v}$

Secretary of State for Defence, decision of 12 December 2007, [2007] UKHL 58; Supreme Court of the Netherlands The State of the Netherlands v. Hasan Nuhanović, No. 12/03324, judgment of 6 September 2013.
} 
The same holds in case a third state is in charge of an operation in its own territory. While the former case can be easily resolved already within EU liability law and the European Convention on Human Rights and Fundamental Freedoms (ECHR), the application of international law is essential for third states as they are not bound by EU law and potentially not even by the ECHR.

Less straightforward has proven to be the case of the responsibility of Frontex, which, as an EU agency, is also bound by the Charter of Fundamental Rights of the European Union (Charter) ${ }^{55}$ as well as ECHR and fundamental rights, as they are protected in the constitutional traditions of the member states. ${ }^{56}$

However, since early on, the position of the agency has been that Frontex is merely the coordinator of the operational cooperation of the member states, and can, thus, not be held responsible for any possible violations that might arise in the context of its operations. In this line of argument, it is the member states that have the operational power and the general control of the operation on the ground and, thus, it is the national authorities that bear the full responsibility for potential violations. ${ }^{57}$

Several compelling arguments exist however that provide conclusive evidence for the prima facie responsibility of Frontex for violations that may occur during its operations. The responsibility for the agency can be either direct, if it is proven that it exercises sufficient control over the wrongful act of a state, or indirect, through contributing to a violation committed by a state. According to Arts. 14-16 ARIO, international responsibility may arise for an organisation from an act that does not as such constitute an unlawful act under international law, but is linked to one that is conducted by a state. In particular, Frontex may incur such responsibility, if it aids or assists the state in the commission of the internationally wrongful act (Art. 14 ARIO), or if it exercises sufficient direction and control over the conduct of the state (Art. 15 ARIO).

\footnotetext{
${ }^{55}$ Article 51 Charter.

${ }^{56}$ Art. 6(2) of the Treaty on the European Union (TEU).

${ }^{57}$ The message that border control activities lie exclusively within the sovereignty of the member states is broadcasted by Frontex on several occasions to stress that the agency does not have independent executive powers. See, for instance, FRONTEX note to the European Parliament regarding fundamental rights, 8 October 2010, 'As regards fundamental rights, FRONTEX is not responsible for decisions in that area. They are the responsibility of the Member states.', Migreurop, 'Frontex Agency: Which Guarantees for Human Rights?', March 2011, p. 22, available at http://www.migreurop.org/IMG/pdf/Frontex-PE-Mig-ENG.pdf; 'As regards fundamental rights, Frontex is not responsible for decisions in that area. They are the responsibility of the Member States.'Ilkka Laitinen, Frontex Executive Director, at LIBE Committee hearing on 'Democratic Accountability in the Area of Freedom, Security and Justice, Evaluating Frontex', 4.10.2010.
} 
Under Art. 14 ARIO, the organisation, would be held responsible under the conditions that a) it had (presumed) knowledge of the circumstances under which the wrongful act took place, ${ }^{58}$ and b) that the act itself would have been wrongful if committed by the organisation.

Concerning Art. 15 ARIO, 'direction and control' can also take the form of a decision taken by the international organisation binding its members, provided that the state does not have sufficient discretion not to comply with the decision. ${ }^{59}$ Joint exercise of direction and control is also deemed possible. ${ }^{60}$ The conduct of the organisation can either be an act or failure to act in case the organisation is under the positive obligation to prevent its member states from committing an internationally wrongful act (Art. 4 ARIO).

This, however, does not mean that the member state hosting the operation is absolved of responsibility. The responsibility of the member states, hosting or participating in the operation is not contested in this contribution. The primary responsibility in border control lies with the member states, which cannot use their membership in an international organization as a way to evade responsibility, ${ }^{61}$ and cannot shift the blame to the agency. ${ }^{62}$ In practice, it is normally the state that has the final word and commits the internationally wrongful act as such.

Similarly, to the agency, states participating in the operation may also incur responsibility for aiding or assisting in a violation conducted by the host state (Art. 16 ARS), for instance to the extent that they have contributed with personnel or assets, as well as funding, technical and logistical support to an operation which resulted in a human rights violation. In this regard, the participating states cannot be exempt from responsibility on the basis that their personnel was under the authority of the host state. This could be the case only if the host state exercised exclusive command and control over the guest officers (Art. 6 ARS), which is not apparent in EBCG operations. ${ }^{63}$

\footnotetext{
${ }^{58}$ International Court of Justice, Corfu Channel Case, (United Kingdom v. Albania), [1949] ICJ Reports 4; H. Shue, Basic Rights, Subsistence, Affluence, and U.S. Foreign Policy, 1980, p. 33.

${ }^{59}$ ARIO Commentary to Article 15, par. 4; Art. 17.

${ }^{60}$ ICJ, Yugoslavia v. France, Preliminary Objections, p. 33, par. 46.

${ }^{61}$ ECtHR, Bosphorus v. Ireland, Application No. 45036/98, judgment of 30 June 2005; The issue is also dealt with in Hirsi with respect to bilateral agreements with Libya. ECtHR, Hirsi Jamaa and Others v. Italy App No 27765/09, judgement of 23 February 2012.

${ }^{62}$ Rijpma Jorrit, 'Frontex: Successful Blame Shifting of the Member states?', (ARI), Real Instituto Elcano, ARI 69/2010, 13//04/2010 (hardcopy), p. 1-4.

${ }^{63}$ PAPASTAVRIDIS, E. (2010) "Fortress Europe' and Frontex: Within or without International Law?' Nordic Journal of International Law,79 (1): 107
} 
To sum up, both hosting member states or third states, and participating states may be responsible for a violation, while Frontex itself can incur responsibility either directly or for aiding and assisting in a violation, either by action or by omission. At the same time, none of the actors may deny their responsibility on the ground of the responsibility of another actor. This creates a rather confusing picture regarding responsibility that has been conceptualised as the problem of many hands.

\subsection{The Problem of Many Hands}

When addressing complex structures, such as the EBCG, the attribution of responsibility is not always crystal clear. Dennis Thompson, the political philosopher who coined the term, discusses the problem of many hands as a difficulty to pinpoint the moral responsibility for political outcomes. ${ }^{64}$ Bovens places this problem in the context of complex organisations, ${ }^{65}$ while it is used in this study in the context of the legal responsibility of actors involved in EBCG operations for violations of fundamental rights. In all cases, the analysis is equally applicable, since the core of the problem is common, it is namely the difficulty to identify who is responsible, in the sense of Hart's Liability-Responsibility, ${ }^{66}$ for a harmful result, when multiple actors are involved.

In situations, such as EBCG joint operations, it is impossible to find one actor that is entirely and independently responsible for the outcome, since that is a collective one. It also becomes practically difficult to distinguish who and to what extent has contributed to which particular part of the outcome, and should be thus held responsible for it. It is first and foremost a problem of proof.

Bovens describes the problem as a practical, ${ }^{67}$ but also as a normative one, in highly problematic cases, where the collectivity, with the sum of the actions of its individual

\footnotetext{
${ }^{64}$ Dennis F. Thompson, 'Moral Responsibility of Public Officials: The Problem of Many Hands', APSR 74, 1980, pp. 905-16, p. 905.

${ }^{65}$ Mark Bovens, The Quest for Responsibility, Accountability and Citizenship in Complex Organizations, Cambridge University Press, 1998, p. 45.

${ }^{66}$ H.L.A. Hart, Postscript: Responsibility and Retribution, in 'Punishment and Responsibility, Essays in the Philosophy of Law', Oxford University Press, Oxford, 1968, pp. 211-230.

${ }^{67}$ 'Complex organisations are surrounded by paper walls.'; 'Policies pass through many hands before they are actually put into effect'; 'Individual continuity is often lacking'. Mark Bovens, The Quest for Responsibility, Accountability and Citizenship in Complex Organizations, Cambridge University Press, 1998, p. 47.
} 
members, meets the criteria, but the same cannot be said for each of its parts. ${ }^{68}$ These are situations, where there is no clear division of tasks and formal responsibilities, or transparency into the stages of preparation and execution, so that the facts but also the de facto responsibilities (Liability Responsibility) become obvious. Both, the clear a priori division of responsibilities and the lack of transparency are long-standing issues in the cases at hand.

The problem of many hands functions as a wall behind which actors may hide their own contribution and shift the blame to other actors involved. This frustrates the attempts of accountability and consequently the prevention of misconduct in the future. In this sense, it is described by Bovens also as a problem of control. ${ }^{69}$

\subsection{Responsibility as nexus}

In order to prevent this gap in accountability, we need to adjust our way of thinking about responsibility to the particularities of the cases where many hands are responsible for the outcome. In EBCG operations, usually no single actor's acts lead entirely and independently to human rights violations. This can be, exceptionally, the case when a violation attributed to the host state, e.g. physical abuse of a migrant, occurs as an isolated incident without the presumed knowledge of the participating states and Frontex.

However, more often than not, it is multiple actions and omissions from several actors that lead to the violation. Thus, responsibility should be seen not as a linear relationship between the conduct of an actor and the harmful result, but as a nexus. It is in this nexus that the separate responsibilities meet and interact through the cooperation of the different actors.

Only when the responsibilities meet, the harmful result can occur. Therefore, the responsibility is a collective one. One may be able to follow the line of responsibility back to each actor, but will not easily be able to fully disentangle the collective responsibility, at least at a prima facie stage, without access to the full facts of the individual case. Trying to establish the individual responsibility of each actor/hand may result in gaps in accountability and the legal protection of those affected by border controls. To achieve the optimal result allocating responsibility, the responsibility should be seen as collective.

\footnotetext{
${ }^{68}$ Mark Bovens, The Quest for Responsibility, Accountability and Citizenship in Complex Organizations, Cambridge University Press, 1998, pp. 47, 48.

${ }^{69}$ Mark Bovens, The Quest for Responsibility, Accountability and Citizenship in Complex Organizations, Cambridge University Press, 1998, p. 49.
} 
International law has tried to deal with the problem of many hands introducing in the DARIO the concept of joint responsibility. The parallel responsibility of more subjects of international law is covered under Art. 48 DARIO, according to which an internationally wrongful act can be attributed to one or more states or international organisations. According to the UN Special Rapporteur on the Responsibility of International Organizations, if an internationally wrongful act can be attributed to one or more states or international organisations, the actors involved are jointly responsible. ${ }^{70}$

\section{Accountability}

After having engaged with issues of responsibility, the question arises, under which framework should this joint responsibility be addressed by judicial bodies. For this purpose, I will first examine the normative conception behind the current paradigm on accountability, and then I will argue in favour of an approach that best fits the needs of a joint cooperative endeavour, such as the EBCG.

\subsection{The traditional approach to accountability: individual accountability}

When assessing the legal framework on accountability regarding human rights violations, we use to do so on the basis of access to justice and effective legal protection, especially looking into the availability of an effective legal remedy. I refer to this approach as individual accountability, i.e. the traditional approach of answering for human rights violations on the level of the individual applicant with measures that redress the effects of the violation on him/her alone.

70 Giorgio Gaja, Special Rapporteur, Second report on responsibility of international organisations, DOCUMENT A/CN.4/541, paras. 8,9. The joint responsibility between member states and agency has also been proposed among others by Goodwin-Gill, The right to seek asylum: Interception at sea and the principle of nonrefoulement, International Journal of Refugee Law 23, p. 447; European Parliament Civil Liberties, Justice and Home Affairs Department, Guild Elspeth, Carrera Sergio, Den Hertog Leonhard, Parkin Joanna (Rapporteurs), 'Implementation of the EU Charter of Fundamental Rights and its Impact on EU Home Affairs Agencies Frontex, Europol and the European Asylum Support Office (EASO)', 2011 available at http://www.europarl.europa.eu/meetdocs/2009_2014/documents/libe/dv/02 study fundamental_rights /02_stud y fundamental rights en.pdf, p. 92-95; Weinzierl Ruth, Lisson Urszula, 'Border Management and Human Rights, A study of EU Law and the Law of the Sea', German Institute for Human Rights, December 2007, available at: http://www.statewatch.org/news/2008/feb/eu-study-border-management.pdf, p. 72. 
Although this approach may be successful in bringing justice to the individual applicant, it is not sufficient when multiple actors are responsible for the harmful result. In other words, although individuals can in case of a violation in the context of a joint operation, get the compensation they are entitled to by bringing a case against the host member state, the responsibility of the other actors, especially Frontex should not be ignored.

Individual accountability, in the sense of remedying a violation for a particular individual, can be reached through less complex, already established judicial avenues. These do not require original academic literature or newly introduced legal arguments that do not guarantee a positive outcome in courts. Nevertheless, other considerations of equal weight allow us to attach certain value to attributing responsibility, where it arises, also to Frontex through legal accountability. In this paper, I argue in favour of passing from 'individual accountability', to what I name 'systemic accountability', seen as a form of accountability that addresses a structural societal problem. I do so using arguments based on justice and the rule of law, inspired by liberal political philosophy, as well as arguments based on strategic litigation.

\subsection{Sketching Systemic Accountability on Rawls' Theory of Justice}

In this section, I use an argument in support of systemic accountability emanating from the political philosophy of John Rawls, as a major example of the dominant liberal political theory. In particular, I use his theory of justice as fairness, as a normative frame of reference. According to Rawls, a particular approach to justice, i.e. justice as fairness, should constitute the foundation of the basic structure of society. This theory is based, according to Rawls, on the common understanding of our uncontroversial and intuitive assumptions about justice. Through the thought experiment of 'the original position', where all people, free from all knowledge of the elements that make them individuals and separate them from the rest of the society, such as their personal interests, capabilities, social position etc., having, however, a basic understanding of a worth-living human life, would reach an agreement on what is justice. Deciding as (theoretically) free and equal beings, on the basis of rationality and self- 
interest, in this experiment, people would construct, according to Rawls, two Principles of Justice. $^{71}$

The first principle of justice (liberty principle) reads:

'Each person has an equal right to a fully adequate scheme of equal basic liberties compatible with a similar system of liberties for all'.

The second principle of justice (difference principle) reads:

'Social and economic inequalities are to be arranged so that they are both:

(a) To the greatest benefit of the least advantaged, consistent with the just savings principle, and

(b) Attached to the offices and positions open to all under conditions of fair equality of opportunity. 72

Rawls's liberalist ideas, especially concerning the application of the two principles in relation to one another, and the higher position he attributes to civil and political rights vis-à-vis social and economic rights are highly controversial. However, for the purpose of this paper, it is not necessary to tackle such questions. Limiting myself to the subject at hand, I will only deal with the application of the first principle of justice, which is connected to civil rights, such as the ones that are under consideration in the case of migrants in an irregular situation: 'Each person has an equal right to a fully adequate scheme of equal basic liberties compatible with a similar system of liberties for all' (emphasis added).

On the basis of the liberty principle, each person's individual rights should be 'compatible with a similar system of liberties for all'. In other words, any particular liberty should fit into a 'theory of people's interests' and should be distributed in the spirit of a 'theory of equal

71 Nik J. de Boer, Fundamental Rights and the EU Internal Market: Just how Fundamental are the EU Treaty Freedoms? A Normative Enquiry Based on John Rawls' Political Philosophy, Utrecht Law Review, Volume 9, Issue 1 (January) 2013, pp. 151-3.

72 Rawls himself has modified these principles. In Political Liberalism, they read as follows:

Each person has an equal claim to a fully adequate scheme of equal basic rights and liberties, which scheme is compatible with the same scheme for all; and in this scheme, the equal basic liberties, and only those liberties, are to be guaranteed their fair value.

Social and economic inequalities are to satisfy two conditions: first, they are to be attached to positions and offices open to all under conditions of fair equality of opportunity; and second, they are to be to the greatest benefit of the least advantaged members of society.

John Rawls, Political Liberalism, New York, NY: Columbia University Press, 1993. 
concern for people's interests'. ${ }^{73}$ Rawls meant for this to be a critique towards the utilitarian account of justice. According to Mill and other classic proponents of utilitarianism, ${ }^{74}$ the ultimate purpose is the maximization of net satisfaction, while in his liberty principle, Rawls imposes restrictions on how satisfaction can be achieved. In this sense, claims or interests that cannot fit within a theory of equal concern for the interests of the others are inadmissible. ${ }^{75}$ This approach is not relevant as such for the purpose of this paper, however, it makes clear indirectly Rawls's opinion, that is also the premise of this argument, namely that the interests of the one are inextricably intertwined to the interests of the many, and a just society can only be achieved through a 'system of liberties for all'. It, therefore, justifies an approach, which can be named for the purpose of this paper, 'systemic accountability'.

The first principle of justice translates in practice in the rulings of the European Court of Human Rights (ECtHR), in particular in the means the Court employs for the reparation of a violation: just satisfaction, individual and general measures. ${ }^{76}$ Rawls speaks of a scheme of equal basic liberties for each person. These liberties can be ensured for the individual with the just satisfaction or individual measures of the ECtHR, that can take the form of measures concerning residence status, reopening of judicial proceedings etc. ${ }^{77}$ The second part of the first principle, however, 'compatible with a similar system of liberties for all', cannot be satisfied with individual accountability, i.e. the traditional approach of answering for human rights violations on the level of the individual applicant with measures that redress the effects of the violation on her/him alone. It is in cases, where the Court finds a consistent and systemic violation, that it orders general measures, in order to deal with the structural problems and prevent further violations. The general measures ordered by the ECtHR range from practical measures, such as the hiring of judges, to changes of jurisprudence or

73 Will Kymlicka, Contemporary Political Philosophy, An Introduction, Second Edition, Oxford University Press, 2002, p. 139.

74 Will Kymlicka, Contemporary Political Philosophy, An Introduction, Second Edition, Oxford University Press, 2002, p. 42.

75 Will Kymlicka, Contemporary Political Philosophy, An Introduction, Second Edition, Oxford University Press, 2002, pp. 42, 139.

${ }^{76}$ In Scozzari and Giunta v. Italy, the Court read in Art. 46 of the Convention the obligation of states to take individual and general measures in order to abide by the judgment of the Court. ECtHR, Scozzari and Giunta v. Italy application no. 39221/98, judgment of 13 July 2000 (\$ 249).

77 The Committee of Experts for the Improvement of Procedures for the Protection of Human Rights (DH-PR), created by the Committee of Ministers of the Council of Europe has developed an inventory of individual measures taken by the ECHR bodies. Available here:

www.coe.int/t/dghl/monitoring/execution/Source/Documents/Docs_a_propos/H-Exec(2006)2_IM_960_en.doc (last accessed 10.05.2015). 
legislative amendments. ${ }^{78}$ For instance, in the case of Kim v. Russia, ${ }^{79}$ where violations of Articles 3 and 5 ECHE were found with respect to the detention of a stateless person in view of his expulsion, the Court, besides the just satisfaction to Mr Kim, also considered it necessary to request that Russia limits detention periods and provides for a mechanism that would allow individuals to bring proceedings for the examination of the lawfulness of their detention pending expulsion.

It is this approach that is expressed with the term systemic accountability: not only remedying the violation for the individual claimant (individual accountability) but putting effort in dealing with the structural issues that underlie and cause or allow for the violation, in order to prevent further similar future violations.

In other words, individual accountability is no longer adequate to achieve justice when the (human rights) problem is not an individual one but a societal one, being consistent and systemic, and affecting a large number of people. Systemic problems need to be dealt with in a structural manner, since a systemic response to violations would lead to a more effective achievement of the first principle of justice, ensuring the same level of satisfaction of these liberties for all members of society. In such cases, a systemic accountability approach is needed.

This approach is not merely the judicial creativity of the ECtHR. According to the Koskenniemi, 'Far from being merely an academic aspect of the legal craft, systemic thinking penetrates all legal reasoning, including the practice of law-application by judges and administrators. ${ }^{80}$

Courts around the world, adopt the same approach, inspired by a generally acceptable perception of justice. For instance, the Colombian Constitutional Court has developed the concept of 'unconstitutional state of affairs'. This describes a situation, where systematic and widespread violations of several constitutional rights that affect a significant number of people have occurred, while the violations of these rights cannot be attributed to only one state authority, but are due to structural deficiencies. The consequence of such a finding

\footnotetext{
${ }^{78}$ The Committee of Experts for the Improvement of Procedures for the Protection of Human Rights (DH-PR), created by the Committee of Ministers of the Council of Europe has developed an inventory of general measures taken by the ECHR bodies. Available here: www.coe.int/t/DGHL/Monitoring/Execution/Source/Documents/Docs_a_propos/HExec(2006)1_GM_960_en.doc (last accessed 10.05.2015).

${ }^{79}$ ECtHR, Kim v. Russia, application no. 44260/13, judgment of 17 July 2014.

80 Koskenniemi, Study on the Function and Scope of the lex specialis rule and the question of self-contained regimesí (ILC(LVI)/SG/FIL/CRD.1 and Add 1), para 29.
} 
would be the request by the Court of the adoption of measures that would ensure the protection not only of those who submitted the claim, but of all individuals in the same circumstances. The Court has applied the concept of unconstitutional state of affairs, inter alia, in the case of internally displaced persons and with respect to individuals held in inhumane detention conditions. ${ }^{81}$

Applying the approach of systemic accountability to the case of violations during Frontexcoordinated joint operations, although the affected individuals could have had their situation remedied by getting compensation from a claim brought against a member state alone, thus achieving individual accountability and the right of the person to a 'fully adequate scheme of equal basic liberties', the promise of systemic accountability would remain unfulfilled if all the public authority actors involved, including Frontex, would not bear their fair share of responsibility (joint responsibility).

\subsection{Systemic Accountability as Limitation of Coercive Power}

The lack of legal accountability of Frontex apart from justice and substantive human rights challenges also raises issues with respect to the rule of law. I will now study this problem through the lens of the rule of law, arguing for systemic accountability.

The origins of the rule of law in western philosophy are to be found among the Greek philosophers, Aristotle, Plato, and the Athenian democrats. However, the concept developed at large into its modern form through the philosophical tradition, which was developed during the times of the Enlightenment, liberalism. In the light of the early liberal thought, the rule of law is seen as effective limitation to state authority in defence of individual liberties. Emanating from the idea of reason, as opposed to the dominance of human desires and the imposition of the law of the fittest, and the idea of equality before the law, the purpose of the principle of the rule of law is to achieve coherence and avoid arbitrariness in the legal system. ${ }^{82}$ It is considered among the foundations of today's liberal-democratic order.

81 Malcom Langford (ed.), Social Rights Jurisprudence, Emerging Trends in International and Comparative Law, Cambridge University Press 2008, pp. 148,149.

82 Read further on the conceptualisation of the rule of law in EU migration and asylum policy, Leonhard den Hertog, The rule of law in the external dimension of EU migration and asylum policy. Organizational dynamics between legitimation and constraint, Wolf Legal Publishers, 2014, pp. 40-85. 
Starting as a 'political ideal', ${ }^{83}$ it evolved also through the jurisprudence of the CJEU ${ }^{84}$ into a constitutional principle of EU law. The Union is 'founded on the values of respect for human dignity, freedom, democracy, equality, the rule of law and respect for human rights' ${ }^{85}$

Dworkin sees the rule of law as the element that binds together the 'seamless web' of the legal order. $^{86}$

Different schools of thought attach different interpretations to the concept of the rule of law.

Divided in two large categories, we can identify the thin version of the rule of law, which sees the rule of law as formal legality, meaning simply that 'the government should act through laws', and the thick version, where fundamental rights (or at least individual liberties) form part and parcel of the principle of the rule of law. ${ }^{87}$ Although I reject the dominant idea of the rule of law as formal legality (thin version), the fact that respect of fundamental rights and refugee law is an essential element to the rule of law cannot be contested even by proponents of the thin version theories since it fits in the positivist philosophical tradition. ${ }^{88}$

Fundamental rights, including refugee protection, as constitutional principles also enshrined in international treaties, stand on the top of the Kelsenian pyramid of norms, ${ }^{89}$ while the Charter of Fundamental Rights of the European Union is, since 2009, the key instrument, against which the compliance of the actions of all the institutions, organs and agencies of the EU is measured. Even, according to the thin interpretation, the rule of law has a strong procedural character and requires that a complete system of remedies needs to be put in place with the view of achieving effective judicial protection for the individual.

Den Hertog has shown, through a thorough analysis of the Treaties and the case law of the CJEU, that in the EU, the concept of the rule of law has developed from a thin to a thick version, however, not to the extent that the most expansive thick version theories would have hoped for. In EU law, fundamental rights are not part of rule of law as such, but the two are

83 Leonhard den Hertog, The rule of law in the external dimension of EU migration and asylum policy. Organizational dynamics between legitimation and constraint, Wolf Legal Publishers, 2014, p. 40.

84 CJEU, Case 294/83, Les Verts v. Parliament [1986] ECR 1339, par. 23.

85 TEU Art. 2.

86 Dworkin R., Taking Rights Seriously, London, Duckworth (1978).

87 See further Leonhard den Hertog, The rule of law in the external dimension of EU migration and asylum policy. Organizational dynamics between legitimation and constraint, Wolf Legal Publishers, 2014, pp. 44-46.

88 Arguments put forward from the side of critical legal theory that are crucial for the understanding and the legitimation of the rule of law, are not relevant for the purpose of this paper.

89 Hans Kelsen, Pure Theory of Law (Reine Rechtslehre), 1934. 
'inextricably linked'. With respect to the understanding of the rule of law within the context of EU law, den Hertog adopts the following definition: the rule of law can be understood as 'effective legal remedies to ensure the protection of human rights'. 90

Key components of the rule of law are also legal certainty and the legitimate expectations of individuals from public authority. Accountability and clear attribution of responsibility are necessary to achieve the above. Lack of accountability leaves a gap on the rule of law, as shown in the work of Montesquieu ${ }^{91}$ and Dworkin, ${ }^{92}$ in which the role of the judiciary is central, as an important safeguard for the rights of the individual against unlawful actions of public authority.

Use of force is an inherent component of EBCG border operations. Officers participating in operations are allowed to use force, including service weapons and ammunition. ${ }^{93}$ Such use of force is legitimised as the exercise of political power. However, in a democratic society that operates on the basis of the rule of law, coercion should be used only as last resort ${ }^{94}$ and within certain limits, i.e. human rights. The accountability of the sovereign is the safeguard, put in place to ensure the enforcement of human rights, as limits to sovereign power. In this classic rule of law approach, which fits within both, the thick and the thin version of the principle, it can be concluded that if the EU is to abide by the rule of law, a systemic approach on legal accountability, covering all actors involved in a violation, is necessary in order to protect individuals against the misuse of coercive powers. Reviewing EBCG operations, in particular, failing to attribute responsibility to all actors involved in the commission of a violation, including the agency, raises challenges with respect to adherence to the rule of law.

\subsection{Systemic Accountability in the Service of Strategic Litigation}

90 Leonhard den Hertog, The rule of law in the external dimension of EU migration and asylum policy. Organizational dynamics between legitimation and constraint, Wolf Legal Publishers, 2014, p. 55.

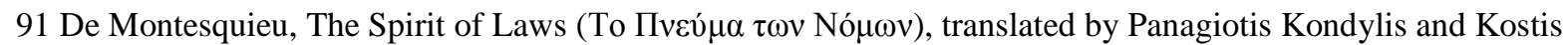
Papagiorgis, Gnosi editions, Athens, 2006.

92 Dworkin R., Taking Rights Seriously, London, Duckworth 1978.

93 Art. 10(6) of Frontex Regulation (consolidated version).

94 Proportionality plays an important role. Force should be used as last resort especially in the case of extended use of force judged on the basis of the numbers of the affected individuals (e.g. detainees in Greece), but also on the basis of the seriousness of the stakes (possibility of infringement of human rights - even some of the most basic ones (life, torture)). 
The arguments discussed under paragraphs 3.2. and 3.3. are legal-philosophical.

Notwithstanding their essential role as matters of principle in an academic or political context, in order for them to lead to realisable conclusions, they need to be backed up with arguments that weigh more in the world of legal practice. The last argument, supporting the attribution of (shared) responsibility to all actors involved in a violation, is, thus, constructed outside the library and fits in the reality of courtrooms.

A lawyer representing an individual, whose rights have been violated in the context of a Frontex operation, will structure the case on the basis of a cost and benefit analysis looking after the interests of her client. In this sense, an attorney would advise her client to seek compensation against the responsible member state, since pursuing a case against Frontex would add to the difficulty of the proceedings. Specifically, attempting to prove the responsibility of Frontex adds an extra level of factual investigation and legal argumentation, making the burden of proof even heavier. Furthermore, such a case would be pioneering and on uncharted territory, since new possibilities for the legal accountability of EU agencies have only just opened up. Lastly, a positive outcome in such a case would not add to the benefit of a client that is not an advocate of the rule of law or a higher philosophical understanding of justice. Since the violation against him would be equally remedied with a case brought against the responsible member state, it would not be reasonable (from a utilitarian point of view) to attempt the more difficult endeavour of filing a claim (also) against Frontex.

Still, what would boost the motivation of the legal practitioner to take up such a case is strategic litigation considerations. Human rights advocates that aim for a structural solution will be able to see real potential in such a top-down approach since holding Frontex accountable can lead to the enforcement of human rights safeguards in all Frontexcoordinated operations across the external EU borders. This top-down approach is proposed as complementary to the approach employed so far, a bottom-up approach, where practitioners would bring to the EU high courts leading cases against member states, with the aim to exercise pressure to the states, which would be translated into political pressure to bring EU migration policies to a direction consistent with human rights.

\subsection{Systemic accountability in the legal remedies}


The approach of individual accountability has, until recently, been the only one possible, as individuals could only bring a case against a state at domestic courts or at the ECtHR and the CJEU, providing that the access to court requirements be met. However, the Lisbon Treaty has opened new pathways for the legal accountability of agencies at the European level. With the entry into force of the Lisbon Treaty, the jurisdiction of the CJEU has been extended to cover also the review of the legality of acts of EU agencies. ${ }^{95}$

Moreover, since Lisbon Treaty constituted the accession of the EU to the ECHR mandatory, and Protocol 14 has been added to the ECHR to facilitate the accession, individuals were expected to be able in the future to lodge complaints against acts of EU agencies before the ECtHR. ${ }^{96}$ However, the CJEU has issued its infamous Opinion 2/13, in which it found the Draft Agreement on the Accession of the European Union to the ECHR incompatible with EU law. ${ }^{97}$ After this Opinion, the future of the accession and the legal accountability of Frontex remain uncertain, casting doubt on the ability of the European human rights system to face the migration challenges of the 21st century. Nevertheless, the remaining option, the procedure before CJEU, leaves some possibilities for effective strategic litigation.

However, it still remains to be seen how systemic accountability will be incorporated in the remedies themselves in a way that ensures the joint responsibility of all actors involved. Concerning the evanescent accession of the EU to the ECHR, this would have been achieved through the 'co-respondent mechanism'. According to the Draft Accession Agreement, the EU or a member state may become party to a case, as a co-respondent to the proceedings before the ECtHR by invitation or decision of the ECtHR upon request of a state in case an application directed against a member state of the EU calls into question EU law. Besides that, an EU member state may also become co-respondent to a case, where the application is directed against the EU. ${ }^{98}$

Consequently, the issue of attribution of responsibility between the EU and its member states will not affect the admissibility of the application, since the co-respondent mechanism will establish the right addressee of the complaint. Thus, a complaint to the ECtHR may be

95 Art. 263 TFEU.

96 Art. 6(2) TEU.

97 CJEU, Opinion 2/13, of 18 December 2014.

${ }^{98}$ Article 3 of the Draft Accession Agreement. 
directed either against a member state of the EU or against the EU itself or both. ${ }^{99}$ If not addressed against the EU, and the latter becomes co-respondent, the EU will be bound by the judgement.

In principle, the ECtHR will not be responsible for allocating the responsibility between the parties, which is deemed as an internal EU issue, since the EU and its member states will be jointly responsible for taking appropriate general or individual measures to remedy the situation and compensate the applicant. ${ }^{100}$

Regrettably, the application of joint responsibility in EU liability law is more challenging. Although the constraints of the current paper do not allow for further elaboration, it suffices to say that the solutions presented by the current judicial precedent of the CJEU on the joint liability of the Union and its member states are not compatible with the international regime on responsibility that supports joint responsibility, and do not fulfill the purpose of systemic accountability. Nevertheless, the jurisprudence of the CJEU is still developing, and there is room for legal interpretations and judicial constructions that support these objectives.

\section{Conclusion}

This paper studies issues of responsibility and accountability for human rights violation in the context of EBCG operations. In sum, it has been shown that the responsibility for human rights violations in the context of EBCG operations is not so much the representation of a linear connection between the conduct of one actor and the harmful result. It is rather a nexus of responsibilities of several actors, which have contributed through their actions and omissions to the violation in a way that creates a collective responsibility.

This includes undoubtadly the host state, either EU member state or third state, but also Frontex and the participating states to the extent of their involvement. The responsibility of the latter two can be either indirect, through assisting the host state in the commission of the internationally wrongful act, or direct, by exercising sufficient degree of direction and control

\footnotetext{
${ }^{99}$ Article 3 of the Draft Accession Agreement.

${ }^{100}$ Claes Monica, Gerards Janneke, 'Netherlands report of XXV FIDE Congress', in Laffranque Julia (ed.) The Protection of Fundamental Rights Post-Lisbon: The Interaction between the Charter of Fundamental Rights of the European Union, the European Convention on Human Rights and National Constitutions, Tartu University Press, Tartu 2012, par. 9.2.
} 
over the commission of the violation. The arguments concerning the allocation of responsibility are drawn from the ILC articles on the international responsibility of states and international organisations, and it is concluded that all actors involved are jointly responsible.

On a second level, the paper introduces the concept of systemic accountability to argue that the joint responsibility of all actors should be investigated before a judicial forum. The concept is proposed to distinguish from individual accountability, which is understood as remedying the violation for a single individual. Instead, systemic accountability focuses on providing a systemic solution to a structural problem that affects a large number of individuals. This translates in the case at hand in starting legal proceedings against all actors involved in a violation, including Frontex.

It has been shown that an approach that favours the attribution of responsibility also to Frontex, would satisfy the requirements for the construction of a just society, the principle of the rule of law, and the aim of strategic litigation, as it would help not only to rectify the harm done to the particular litigant engaged in the lawsuit but also prevent further violations.

Finally, the model of joint responsibility and systemic accountability needs to be substantiated in practice with further research concerning the division of responsibility among the relevant actors, and most importantly, the examination of remedies and procedures that constitute the judicial review by the CJEU. 